\title{
Pengaruh Sosialisasi Politik Komisi Terhadap Partisipasi Pemilih Pemula Pada Pilkada Kota Padang Tahun 2018
}

\author{
M. Ilham Wahyudi Prasetyo ${ }^{1}$, M. Fachri Adnan ${ }^{2}$ \\ 1,2Universitas Negeri Padang \\ Email: yuniaulia1212@gmail.com, fachriadnan@fis.unp.ac.id
}

\begin{abstract}
Abstrak
Penelitian ini didasari oleh jumlah partisipasi pemilih pemula pada pemilihan kepala daerah Kota Padang pada tahun 2018 yakni 64,05\%, dimana angka ini berada dibawah target dari Komisi Pemiliham Umum Kota Padang atau persentase Komisi Pemilihan Umum nasional yakni $70 \%$ pada pilkada serentak yang dilaksanakan pada tahun 2018. Kota Padang juga berada pada tingkat terendah diantara kota/ kabupaten di Provinsi Sumatera Barat yang melaksanakan pilkada serentak. Alasan peneliti menjadikan pemilih pemula sebagai objek penelitian ini dikarenkan pemilih pemula rentan dimobilisasi dan pemilih pemula juga belum terlalu memahami bagaimana peran mereka saat pilkada selain memberikan hak suara pada pilkada Kota Padang tahun 2018. Komisi Pemilihan Umum sendiri telah memberikan sosialisasi politik bak kepada masyarakat umum ataupun pemilih pemula. Penelitian ini bertujuan melihat apa pengaruh sosialisasi politik Komisi Pemilihan Umum Kota Padang terhadap partisipasi pemilih pemula saat pilkada Kota Padang pada tahun 2018. Metode penelitian yang digunakan adalah metode asosiatif dengan pendekatan kuantitatif. Responden dalam penelitian ini adalah pemilih pemula dengan rentan um 17-23 tahun yang ada di kota padang yang diambil menggunakan tekhnik stratified random sampling. Hasil dari penelitian ini menjelaskan bahwa sosialisasi politik yang dilakukan oleh Komisi Pemilihan Umum Kota Padang terhadap partisipasi pemilih pemula memiliki pengaruh yang siginifikan (58\%).
\end{abstract}

Kata kunci: sosialisasi politik, komisi pemilihan umum, partisipasi pemilih pemula, pilkada

\begin{abstract}
This research is motivated by the number of voters participating in the election of mayor and deputy mayor of Padang which is $64.05 \%$, this figure is below the target of the Padang city election commission or the national percentage target of $70 \%$ in simultaneous local elections. The Padang city is also ranked lowest among cities/ regencies in West Sumatra province which carry out simultaneous regional elections. The reason for the beginner voters to become the object of this research is because the beginner voters are vulnerable voters to be mobilized and also the beginner voters do not yet fully understand their role in the election other than giving their voting rights. The General Election Commission itself has provided political socialization to both the general public and the novice voters themselves regarding the elections. This study aims to see what the influence of political socialization of the Padang city electoral commission is on the participation of first time voters during the election of the city of Padang in 2018. The research method used is an associateve method with a quantitative approach. The data in this study are primary and secondary data. Primary data is taken by distributing questionnaires about the socialization of the general election commission and the participation of political voters to the respondents. Respondents in this study were novice voters in Padang city who were taken using simple random sampling techniques. The results of the study have a significant effect between the political socialization of the electoral commission on the participation of beginner voters with the adjusted $R$ square value of $58 \%$ and sig 0,000 which means that ho is rejected and ha is accepted.
\end{abstract}

Keywords: political socialization, electoral commissions, beginner voter participation

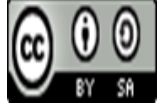

Received: July 25, $2019 \quad$ Revised: July 30, 2019 Available Online: July 31, 2019 


\section{Pendahuluan}

Kegiatan demokrasi di Indonesia saat ini sedang berjalanmenuju kemajuan, dapat dilihat dimana rakyat yang akan memegang kekuasaan tertinggi disuatu pemeritahan. Demokrasi berasal dari bahasa yunani, yakni demos yang berarti rakyat dan cratein yang berarti memerintah. Jika dua kata tersebut digabungkan maka dapat ditarik makna dari kata demokrasi yakni pemerintahan rakyat atau rakyat yang memerintah. Dalam buku Muchtar Pakpahan (2010:134) Abraham Lincoln mengatakan bahwa demokrasi adalah pemerintahan dari rakyat, oleh rakyat, dan untuk rakyat.

Pemilihan kepala daerah (Pilkada) merupakan salah satu bentuk pelaksanaan kegiatan demokrasi di Indonesia, dimana kepala daerah dipilih langsung oleh rakyat. Sosilalisasi mengenai pillkada tentu dibutuhkan guna memberikan pemahaman kepada masyarakat mengenai pilkada itu sendiri. Sosialisasi politik berfungsi dalam mengebangkan srta memperkuat sikap politik di masyarakat umum tidak terkecuali pemilih pemula yang baru mengikuti pilkada itu sendiri. Sosialisasi politik melibatkan keluarga, sekolah, dan lembagalembaga tertentu yang ada dalam masyarakat. Adapun fungsi dari sosialisasi politik anatara lain untuk meningkatkan pengetahuan dan pemahaman masyarakat tentang kehidupan politik, serta mendorong timbulnya partisipasi yang maksimal dalam kehidupan berpolitiknya. Hal ini senada dengan konsep demokrasi yang telah dijelaskan dimana rakyat harus berpartisiapasi dalam kehidupan berpolitik.

Kota Padang yang merupakan salah satu kota yang ikut serta dalam pilkada serentak di Provinsi Sumatera Barat, dan sluruh tahapan pilkada tertuang dalam Peraturan Komisi Pemilihan Umum Republik Indonesia (PKPU RI) No. 1 Tahun 2017 tentang Tahapan, Program dan Jadwal Penyelenggaraan Pemilihan Gubernur, Wakil Gubernur, Bupati dan Wakil Bupati, dan/atau Walikota dan Wakil Walikota Tahun 2018. Kota Padang memiliki dua pasang calon Walikota dan Wakil Walikota yakni pasangan nomor urut satu Emzalmi sebagai calon Walikota dan Desri Ayunda sebagai calon Wakil Walikota yang diusung oleh partai Gerindra, Golkar, Demiokrat, PDIP, PPP, PKB, Nasdem. Sedangkan pasangan calon nomor urut dua yakni Mahyeldi sebagai calon Walikota dan Hendri Septa sebagai calon Wakil Walikota yang diusung oleh partai PKS dan PAN.

Namun diantara empat kabupaten/kota yang ikut serta pada Pilkada Provinsi Sumatera Barat tahun 2018, Kota Padang menjadi kota dengan persentase pemilih yang menggunakan hak pilih paling rendah yakni 64,05\%, sedangkan Kabupaten Sawahlunto menjadi kabupaten dengan persentase pemilih yang menggunakan hak suara tertinggi yakni 77,57\% dan disusul oleh Kota Pariaman dengan persentase $73,9 \%$, dan Kota Padang Panjang dengan persentase $71 \%$.

Di Kota Padang sendiri, Komisi Pemilihan Umum Kota Padang sendiri telah gencar melakukan sosialisasi terkait pemilih kepala daerah baik secara langsung maupun melalui media sosial yang ada saat ini, dan juga melalui spanduk dan iklan yang dipasang di surat kabar dan papan jalan. Komisi Pemilihan Umum Kota Padang menyasarkan sosialisasi politik kepada pemilih pemula di Kota Padang dengan cara melakukan kegiatan sosialisasi di sekolah menengah atas dan kampus-kampus di sekitar Kota Padang untuk menyebarkan informasi terkait pemilihan umum.

Komisi Pemilihan Umum berharap bahwa partisipasi bisa meningkat hingga $70 \%$, namun pada kenyataannya, persentase pada pilkada Kota Padang tahun 2018. Disinlah peran sosialisasi politik Komisi Pemilihan Umum dibutuhkan guna mampu menigkatkan partisipasi politik masyarakat di Kota Padang Khususnya pemilih pemula, untuk menggunakan hak suara mereka guna terselenggaranya kegiatan demokrasi yang baik di Kota Padang.

Berdasarkan hal tersebut, peneliti bermaksud mengangkat permasalahan tersebut dengan judul Pengaruh Sosialisasi Politik Komisi Pemilihan Umum Kota Padang terhadap 
Partisipasi Pemilih Pemula pada Pemilihan Kepada Daerah (Pilkada) Kota Padang tahun 2018.

\section{Landasan Teori}

\section{Sosialisasi Politik}

Sosialisasi politik merupakan sebuah usaha/kegiatan memberikan pengenalan kepada individu agar individu tersebut mengerti sistem politik dan dapat membuat reaksi politik atas gejala politik yang terjadi.

M. Rush dan P. Althoff (2008) membatasi sosialisasi politik sebagai "suatu proses memperkenalkan sistem politik pada seseorang, dan bagaimana orang tersebut menentukan tanggapan serta reaksi - reaksi terhadap gejala politik". Sedangkan Gabriel A. Almond membatasi sosialisasi politik sebagai "bagian dari proses sosialisasi yang khusus membentuk nilai - nilai politik, yang menujukan bagaimana seharusnya masing - masing anggota masyarakat berpartisipasi dalam sistem politiknya". Jadi dapat disimpulkan bahwa sosialisasi politik memiliki dua hal penting yakni dengan adanya proses dan tujuan. Proses yang dimaksud disini adalah penanaman nilai - nilai, pengetahuan, kepercayaan - kepercayaan, sikap politik dan harapan politik. Sedangkan pada bagian tujuan yang dimaksud adalah partisipasi dari masyarakat dalam proses kehidupan politik.

\section{Partsipasi Politik}

Partisipasi politik merupakan kegiatan seseorang atau kelompok orang yang ikut serta secara aktif dalam kehidupan berpolitik, yaitu dengan cara memilih pimpinan negara dan secara langsung atau tidak langsung mempengaruhi kebijakan yang dibuat oleh pemerintah.

Dalam sebuah negara demokratis, yang mendasari sebuah konsep partisipasi politik adalah bahwa kedaulatan ada di tangan rakyat, yang dilaksanakan melalui kegiatan bersama untuk mencapai tujuan serta masa depan sebuah negara itu dan untuk menentukan orangorang yang akan memegang posisi pemimpin.

Dari pengertian mengenai partisipasi politik diatas maka dapat ditarik kesimpulan bahwa partisipasi politik adalah ikut sertanya individu atau kelompok sebagai warga negara dalam proses kehidupan politik yang berupa kegiatan yang positif dan dapat juga berupa yang negatif yang bertujuan untuk berpartisipasi aktif dalam kehidupan politik dalam rangka mempengaruhi kebijakan yang dibuat oleh pemerintah.

\section{Komisi Pemilihan Umum (KPU)}

Komisi Pemilihan Umum adalah lembaga negara yang menyelenggarakan pemilihan umum di Indonesia yang bersifat nasional, tetap dan mandiri (independen). Pemilihan umum yang diselenggarakan oleh komisi pemilihan umum meliputi pemilihan Umum Anggota DPR/DPD/DPRD, Pemilihan Umum Presiden dan Wakil Presiden, serta Pemilihan Umum Kepala Daerah dan Wakil Kepala Daerah. Karena kedudukan komisi pemilihan umum yang tidak ditentukan dalam UUD 1945, makan dapat diartikan bahwa kedudukan komisi pemilihan umum tidak bisa disejajarkan dengan lembaga- lembaga negara yang telah ditentukan dalam UUD 1945. Wewenang yang dimiliki oleh Komisi Pemilihan Umum, hanya ditegaskan dalam Pasal 22E ayat (5) UUD 1945 yaitu Pemilihan umum diselenggarakan oleh suatu komisi pemilihan umum yang bersifat nasional, tetap, dan mandiri. Komisi pemilihan umum dengan demikian adalah penyelenggara pemilihan Umum, dan sebagai penyelenggara yang bersifat nasional, tetap dan mandiri(independen).

Kedudukan Komisi Pemilihan Umum tidak dapat disejajarkan dengan lembagalembaga negara lain yang kewenangannya ditentukan dan diberikan oleh UUD 1945. Hal tersebut dikarenakan dalam Pasal 22E UUD 1945, nama Komisi Pemilihan Umum tidak 
disebutkan secara eksplisit dan tidak ditulis dengan huruf kapital. Namun nama Komisi Pemilihan Umum telah disebutkan secara pasti dalam Undang-Undang Nomor 22 Tahun 2007 tentang Penyelenggara Pemilihan Umum.

\section{Peranan Komisi Pemilihan Umum dalam meningkatkan Partisipasi Pemilih Pemula}

Komisi Pemilihan Umum mempunyai tanggungjawab yang besar dalam meningkatkan partisipasi masyarakat dalam kegiatan pemilihan umum, bagaimana Komisi Pemilihan Umum menjalankan tugasnya sebagai penyelenggara pemilihan umum dapat menjadi dorongan bagi masyarakat untuk ikut berpartisipasi dalam pemilihan umum. Sosialisasi dan pengetahuan yang diberikan oleh Komisi Pemilihan Umum dapat berupa fasilitas, seminar maupun diskusi bersama masyarakat.

Dalam menjalankan kegiatan sosialisasi pemilih, Komisi Pemilihan Umum berpedoman pada PKPURI No. 8 Tahun 2017 tentang Sosialisasi, Pendidikan Pemilih, dan Partisipasi Masyrakat Dalam Pemilhan Gubernur dan Wakil Gubernur, Bupati dan Wakil Bupati, dan/atau Walikota dan Wakil Walikota. Didalam peraturan tersebut dijelaskan bahwa sosialisasi pemilu adalah proses penyampaian informasi tentang tahapan dan program dalam penyelenggaraan pemilihan. Pada pasal 4 dinyatakan bahwa pemilih pemula merupakan salah satu sasaran sosialisasi pemilu.

Dalam peraturan tersebut, Komisi Pemilihan Umum berpedoman pada tiga belas asas yang tertuang di pasal 2 PKPURI No. 8 Tahun 2017, antara lain adalah: Mandiri, Jujur, Adil, Kepastian Hukum, Tertib, Kepentingan Umum, Keterbukaan, Proporsional, Profersionalitas, Akuntabilitas, Efisiensi, Efektivtas, Aksesbilitas.

Sementara itu materi yang diberikan kepada masyarakat adalah materi mengenai tahapan pilkada dan jadwal pelaksanaan pilkada sesuai dengan pasal 7 poin a PKPURI No. 8 tahun 2017 yakni: (1) Pemutakhiran data dan daftar pemilih. (2) Pencalonan dalam pemilihan. (3) Kampanye dalam pemilihan.(4) Dana kampanye dalam pemilihan. (5) Pemungutan, penghitungan, dan rekapitulasi hasil penghitungan suara pemilihan. (6) Penetapan pasangan calon dalam pemilihan

Sedangkan sosialisasi sendiri dilakukan melalui pertemuan tatap muka (seminar, workshop, pelatihan, rapat kerja, simulasi, dan metode tatap muka lainnya), media massa cetak, media massa elektronik, dan alat peraga sosialisasi (spanduk, banner, baliho, umbulumbul)

\section{Hubungan Sosialisasi Politik dengan Partisipasi Politik}

Michael Rush dan Philip Althoff (2008) menganggap partisipasi sebagai akibat dari sosialisasi politik namun perlu diingat bahwa partisipasi politikpun memiliki pengaruh terhadap sosialisasi politik, tanpa partisipasi politik, sosialisasi politikpun akan sulit berjalan dengan baik.

Jadi dapat disimpulkan bahwa sosialisasi politik dan partisipasi politik memiliki kaitan satu sama lainnya, sosialisasi politik mengandung unsur informasi politik, dimana informasi politik ini nantinya akan menjadi acuan bagi para pemilih pemula untuk terlibat dalam kegiatan pemilihan kepala daerah baik dalam memberikan suara ataupun mengikuti kampanye salah satu pasangan calon. Kemudian dalam sosialisasi politik juga terdapat unsur yang mempengaruhi kepercayaan masyarakat terhadap pasangan calon yang dipilihnya, maka kepercayaan masyarakat akan berpengaruh kepada partiipasi dari masyarakat tersebut.

\section{Metode Penelitian}

Metode Penelitian yang digunakan dalam penelitian ini adalah metode asosiatif dengan pendekatan kuantitatif, dimana metode asosiatif bertujuan untuk melihat hubungan kausal 
atau sebab akibat antara variabel bebas dan variabel terikat. Sedangkan pendekatan yang digunakan dalam penelitian ini adalah pendekatan kuantitatif. Dikatakan pendekatan kuantitatif karena dalam penelitian ini analisisnya menggunakan data numerik atau angka yang diolah dengan menggunakan metode statistic. Populasi yang digunakan dalam penelitian ini adalah pemilih pemula dari tiga kecamatan di kota Padang yakni kecamatan Koto Tangah, kecamatan Kuranji, dan kecamatan Padang Utara yang diambil menggunakan tekhnik stratified random sampling, dengan menggunakan rumus slovin diperoleh sampel yang digunakan sebanyak 99 responden dan tekhnik yang digunakan adalah simple random sampling. Data yang ada dalam penelitian ini dikumpulkan melalui penyebaran angket dengan 4 opsi jawaban berdasarkan pengukuran skala likert yang terdiri dari sangat setuju, setuju, tidak setuju, sangat tidak setuju. Kemudian tekhnik analisis yang dilakukan menggunakan tekhnik analisis regresi linear sederhana. Kemudian untuk mendapatkan gambaran umum mengenai kedua variabel juga digunakan frekuensi, mean, dan TCR (Tingkat Capaian Responden)

\section{Hasil dan Pembahasan}

Untuk Untuk menjawab rumusan masalah mengenai apakah terdapat pengaruh antara sosialisasi politik komisi pemulihan umum terhadap partisipasi pemilih pemula, maka dapat dilihat hasil analisis data penelitian sebagai berikut

Tabel 1. Hasil Kontribusi (R) Variabel Sosialisasi Politik Komisi Pemilihan Umum terhadapPartisipasi Pemilih Pemula

\begin{tabular}{|c|c|c|c|c|c|}
\hline \multicolumn{6}{|c|}{ Model Summary } \\
\hline Model & $\mathrm{R}$ & R Square & $\begin{array}{l}\text { Adjusted } \\
\text { R Square }\end{array}$ & $\begin{array}{l}\text { Std. Error of } \\
\text { the Estimate }\end{array}$ & $\begin{array}{l}\text { Durbin- } \\
\text { Watson }\end{array}$ \\
\hline 1 &, $765^{\mathrm{a}}$ &, 585 &, 580 & ,650 & ,650 \\
\hline
\end{tabular}

a. Predictors: (Constant), sosialisasi_KPU

b. Dependent Variable: pertispasi_pemilih_pemula

Sumber: Hasil Pengolahan Data Penelitian 2019

Berdasarkan tebel di atas dapat di pahami bahwa, nilai Adjusted $R$ Square sebesar 0,580, yang artinya pengaruh variabel sosialisasi politik Komisi Pemilihan Umum terhadap partisipasi pemilih pemula sebesar 58\%. Sisanya sebesar $42 \%$ dipengaruhi oleh variabel lain yang tidak diteliti dalam penelitian ini. Selanjutnya untuk memperkuat interpretasi bahwa pengaruh variabel sosialisasi politik Komisi Pemilihan Umum terhadap partisipasi pemilih pemula adalah signifikan dapat dilihat dari tabel anova (F) berikut ini:

Tabel 2. Hasil Uji Anova (F) Variabel Sosialisasi Politik Komisi Pemilihan Umum terhadapPartisipasi Pemilih Pemula

\begin{tabular}{c|l|r|r|r|c|c}
\hline \multicolumn{7}{c|}{ ANOVA $^{\mathrm{a}}$} \\
\hline $\begin{array}{c}\text { Model } \\
1\end{array}$ & Regression & Sum of Squares & df & Mean Square & F & Sig. \\
& Residual & 14.404 & 1 & 14.404 & 136.548 & $.000^{\mathrm{b}}$ \\
\hline & Total & 10.232 & 97 & .105 & & \\
\hline
\end{tabular}

a. Dependent Variable: partisipasi pemiih pemula

b. Predictors: (Constant), sosialisasi kpu

Sumber: Hasil Pengolahan Data Penelitian 2019 
Berdasarkan tabel di atas, nilai signifikansi sebesar 0,000 lebih kecil dari 0,05 sehingga dapat disimpulkan bahwa Ho ditolak dan Ha diterima yang berarti terdapat pengaruh variabel sosialisasi politik Komisi Pemilihan Umum terhadap partisipasi pemilih pemula pada pilkada Kota Padang tahun 2018. Sehingga dapat disimpulkan bahwa sosialisasi politik komisi pemilihan umum memiliki pengaruh sebesar 58\% terhadap partisipasi pemilih pemula dan bias dipercaya $100 \%$, dan bias digunakan untuk memprediksi pengaruh sosialisasi politik komisi pemilihan umum terhadap partisipasi pemilih pemula.

Berdasarkan hasil temuan yang telah dijelaskan bahwa peneliti memaparkan tentang Pengaruh Sosialisasi Politik Komisi Pemilihan terhadap Partisipasi Pemilih Pemula pada Pilkada Kota Padang tahun 2018. Setelah dilakukan penelitian dan telah dilanjutkan dengan menganalisis data dari analisis data yang telah dilakukan hal ini membuktikan bahwa secara simultan, variabel Sosialisasi Politik Komisi Pemilihan Umum memiliki pengaruh terhadap Partisipasi Pemilih Pemula dengan nilai signifikan 0.000. berarti Ho ditolak dan Ha diterima.

Hasil penelitian ini memperkuat teori-teori yang telah dijelaskan pada bagian kajian teori bahwa sosialisasi politik berpengaruh pada partisipasi masyarakat termasuk pemilih pemula yang belum mengetahui sepenuhnya peran mereka dalam proses politik. Begitu juga dari teori yang didapatkan dari Gabriel A. Almond juga terindikasi bahwa sosialisasi politik dapat berpengaruh positif untuk meningkatkan partisipasi politik masyarakat.Sosialiasi Politik yang telah di lakuka Komisi Pemilihan Umum dan Partai politik yang mengusung kedua pasangan calon walikota dan wakil walikota di Kota Padang memberikan pengaruh yang signifikan terhadap partisipasi politik pemilih pemula yang ada di Kecamatan Padang Utara, Kecamatan Koto Tangah dan Kecamatan Kuranji. Sesuai dengan penelitian yang telah dilakukan oleh Lisa Apriani (2012) dengan judul Hubungan Sosialisasi Politik dengan Partisipasi Politik Masyarakat pada Pemilihan Umum Kepala Daerah (Pemilukada) Walikota 2012 Kota Tanjung Pinang. Penelitian tersebut menyimpulkan jika semakin tinggi sosialisasi politik maka tingkat partisipasi politik masyarakat akan semakin tinggi pula. Hal ini disebabkan karna sosialisasi politik mengandung informasi penting mengenai hal-hal yang terkait pemilukada itu sendiri seperti nama pasangan calon, tata cara memilih, dan peran masyarakat dalam pemilukada tersebut

Informasi-informasi tersebut yang menjadi salah satu pendorong minat masyarakat khsusnya pemilih pemula yang baru mengikuti pemilihan umum sebanyak satu sampai dua kali, oleh karna itu informasi dasar seperti itu sangat dibutuhkan oleh pemilih pemula agar bisa berpartisipasi dalam pemilukada ataupun pemilu

Dari penjabaran diatas, dapat ditarik kesimpulan dalam penelitian ini bahwa di Kota Padang di Kecamatan Padang Utara, Kecamatan Koto Tangah dan Kecmatan Kuranji, Sosialisasi Politik memberikan pengaruh yang cukup besar dalam berpartisipasinya pemilih pemula dalam pilkada Kota Padang tahun 2018. Semakin banyak sosialisasi poitik yang dilakukan Komisi Pemilihan Umum maka akan meningkatkan partisipasi pemilih pemula dalam pemilu maupun pilkada. Sehingga peran Komisi pemilihan Umum untuk terus memberikan sosialisasi dan pendidikan politik kepada masyarakat dan juga kepada pemilih pemula dengan lebih baik agar pemilih pemula mengetahui peran mereka pada saat adanya pilkada ataupun pemilu. Dengan demikian, dinyatakan bahwa secara keseluruhan sosialisasi politik berpengaruh kepada partisipasi pemilih pemula pada pilkada Kota Padang tahun 2018.

\section{Kesimpulan}

Berdasarkan hasil temuan dan pembahasan yang telah dijelaskan sebelumnya, maka dapat penulis ambil simpulkan bahwa Pengaruh sosialisasi politik komisi pemilihan umum terhadap partisipasi pemilih pemula memiliki nilai Adjust $R$ Square 0,580, yang artinya pengaruh variabel sosialisasi politik komisi pemilihan umum terhadap partisipasi pemilih pemula sebesar 58\%. Dalam hal ini sosialisasi politik komisi pemilihan umum memiliki 
pengaruh signifikan terhadap partisipasi pemilih pemula. Secara parsial nilai signifikansi variabel lebih kecil dari 0,05, maka Ho di tolak dan Ha diterima.

\section{Daftar Pustaka}

Adnan, M. F. (2012). Perilaku Memilih Pada Pemilihan Kepala Daerah Secara Langsung. Padang: UNP Press.

Damsar. (2011). Pengantar Sosiologi Pendidikan. Jakarta: Prenada Media.

Efriza. (2012). Political Explore : Sebuah Kajian Ilmu Politik. Bandung: Alfabeta.

Kurniawan, R. C. (Januari 2013). Orientasi Politik Pemilih Pemula Pada Pilkada Pringesewu 2011 (Studi Pada Siswa/i SMUN Di Kabupaten Pringsewu). Jurnal Ilmu Hukum, $7(1)$.

Natalia, A. (2015). Peran Partai Politik Dalam Mensukseskan Pilkada Serentak Di indonesia Tahun 2015. Jurnal TAPIs,11(1).

Nimmo, D. (2010). Komunikasi Politik Khalayak dan Efek. Bandung: Remaja Rosdakarya.

Pakpahan, Muchtar, (2010), Ilmu Negara dan Ilmu Politik. Jakarta: Bumi Intitarma Sejahtera.

Pratama. Zulfikar, Wuri Handayani dan Yasnita Yasin, Persepsi Pemilih Pemula Terhadap Pemilu Legislatif Tahun 2014, Jurnal PPKN UNJ ONLINE, 2(4).

Peraturan Komisi Pemilihan Umum Nomor 1 Tahun 2017 Tentang Tahapan, Program dan Jadwal Penyelenggaraan Pemilihan Gubernur, Bupati, dan Wakil Bupati, dan/atau Walikota dan Wakil Walikota Tahun 2018

Putri, M. P. (2016). Peran Komisi Pemilihan Umum Dalam Sosialisasi Pemilu Sebagai upaya Untuk Meningkatkan Partisipasi Politik Masyarakat Pada Pemilu Presiden tahun 2014 di Kalimantan Barat. ejurnal Ilmu-Komunikasi, 30-34.

Sasmita, Siska, Peran Informasi Politik Terhadap Partisipasi Pemilih Pemula Dalam Pemilu/ Pemilukada, Jurnal Ilmiah Administrasi Publik dan pembangunan, 2(1)

Syarif, M. (2016). Pengaruh Sosialisasi Politik dan Status Sosial Ekonomi Terhadap Partisipasi Politik pada Pemilihan Walikota 2015 di Kelurahan Air Putih Kota Samarinda. e-Jurnal Pemerintahan Integratif, 4(4).

Undang- Undang Nomor 2 Tahun 2011 Tentang Partai Politik

Undang- Undang Nomor 8 Tahun 2015 Tentang Pemilihan Gubernur, Bupati, dan Walikota Undang- Undang Nomor 7 Tahun 2017 Tentang Pemilihan Umum

Winardi. (2010). Menyoal Independensi dan Profesionalitas Komisi Pemilihan Umum Daerah Dalam Penyelenggaraan Pemilihan Kepala Daerah. Jurnal Kostitusi, 3(2) 